\title{
Effects of nitrogen applied after the last cut in autumn on a tall fescue sward. II. Uptake and recycling of nitrogen in the sward during winter
}

\author{
G. Lemaire ${ }^{1}$ and N. Culleton ${ }^{2}$ \\ 1 INRA Station d'Ecophysiologie des Plantes Fourragères, 86600 Lusignan, France \\ 2 Agricultural Institute, Johnston Castle Research Center, Wexford, Ireland
}

(received 17-11-1987, accepted 6-12-1988)

Summary - The previous paper showed that autumn nitrogen supply affected the earliness of spring gowth in tall fescue (cv. Clarine) at Lusignan, west central France. This paper deals with the dynamics of nitrogen uptake during winter.

The apparent recovery of nitrogen was $58 \%$ in $1982-1983$ from an early cut and $33 \%$ from a later autumn cut; the differences in apparent $N$ recovery between early and late autumn cuts were smaller in 1984-1985.

It was shown that during winter, most of the nitrogen had been taken up by the sward by December. It was estimated that, by the end of winter, between $40-50 \%$ of the total nitrogen in the aerial biomass was present in the new tillers. Thus, most of the nitrogen needed for tillering came from recycling. The large leaves formed in autumn were replaced by smaller leaves during December-January and this substitution of large leaves by smaller ones allowed a surplus of nitrogen to be released for the development of new tillers.

The results suggest that it is important to have sufficient nitrogen present in autumn so that tillering can proceed during winter.

nitrogen fertilisation - sward management - nitrogen uptake - nitrogen recycling - litter - senescence

Résumé - Effet d'un apport d'azote après la dernière coupe d'automne sur une prairie de fétuque élevée. II. Prélèvement et recyclage de l'azote dans la végétation au cours de l'hiver. L'article précédent montrait que l'apport d'azote après la coupe d'automne augmentait la précocité de croissance de la fétuque élevée (cv. Clarine) au printemps suivant à Lusignan (centre-ouest de la France). Ce présent article a pour objet d'étudier la dynamique des prélèvements d'azote par la prairie au cours de l'hiver.

Le recouvrement apparent de l'azote apporté était de 58\% en 1982-1983 pour un apport et une coupe précoce d'automne et il n'était que de 33\% après un apport et une coupe tardive. Les différences entre les dates de coupes précoces et tardives ont été plus faibles lors de l'hiver 1984-1985.

Nous avons pu montrer que l'essentiel de l'azote apporté est prélevé par la prairie dès la mi-décembre et que près de 40-50\% de l'azote suplémentaire est utilisé dans les nouvelles talles qui se forment au cours de l'hiver. Ainsi, l'essentiel de l'azote qui sert à l'édification des nouvelles talles pendant l'hiver a déjà été prélevé par la prairie durant le mois de décembre et est réutilisé par la suite grâce au recyclage lors de la sénescence des vieilles feuilles. Les grandes feuilles formées à l'automne en conditions de température élevée sont progressivement remplacées par des feuilles plus petites formées à plus basses températures. Cette substitution laisse un solde positif d'azote qui peut être utilisé pour la croissance des jeunes talles à une période ou l'absorption d'azote du sol est limitée par les faibles températures.

Ces résultats tendent à prouver que la nutrition azotée doit être suffisante avant l'hiver pour que le tallage puisse se réaliser pendant cette période.

fertilisation azotée - gestion d'un peuplement - prélèvement d'azote - recyclage d'azote - litière - sénescence

\section{Introduction}

There is very little information available on the quantities of nitrogen available for uptake by the grass swards during winter. Corall and Clement (1965) have shown that absorption of nitrogen during winter by mediterranean ecotypes of tall fescue was lower than that of north european types despite their higher growth rates during this period. They conclude that mediterranean ecotypes had a higher capacity for absorption in autumn and that the recycling of nitrogen during winter was sufficient to provide for their growth. 
Tomka and Lihan (1976) reported that the application of nitrogen in autumn has a large effect on spring growth, provided it is not applied too late. These authors indicated that if the application was too late, losses by volatilisation became important. Jones et al. (1977) working in a Bromus mollis sward using $15 \mathrm{~N}$ techniques have shown that after an application of $100 \mathrm{~kg} \mathrm{~N}$ in October, $33 \%$ of the nitrogen was accumulated in the aerial plant parts during winter, $61 \%$ remained in the soil plus roots, and $10 \%$ was lost by leaching. When $500 \mathrm{~kg} \mathrm{~N} / \mathrm{ha}$ was applied in October, they found $34 \%$ in the aerial plant parts, $24 \%$ in the soil plus roots, $14 \%$ lost by leaching and $28 \%$ lost by volatilisation. Savage (1978) showed that the aerial biomass was greatly increased after an application of $56 \mathrm{~kg} \mathrm{~N} / \mathrm{ha}$ in autumn. These results suggest that most of the nitrogen applied had beed absorbed by plants.

All these results suggest that the risks of losses by leaching and/or by volatilisation after nitrogen application in autumn are important only at very high levels of $N$. At moderate levels of $N$ supply, most of the nitrogen is stored by the plant (aerial parts and roots) or immobilized in the soil by microbial biomass.

The effects of $\mathrm{N}$ supply in autumn on an overwintering sward of tall fescue was studied at Lusignan and the results presented in a previous paper (Lemaire and Culleton, 1989). It was showed that the effect of nitrogen applied in autumn on growth was immediate, and that there was no noticeable effect on growth in the following spring. There were no available residues of nitrogen persisting after the winter in the soil.

A study of the dynamics of nitrogen uptake by sward during winter is necessary to fully understand the effects of autumn application of nitrogen. This paper examines the movement of nitrogen in the sward during winter. Due to the importance of leaf senescence during winter (Lemaire, 1985), the recycling of nitrogen within the plant and the return of nitrogen to the soil by litter must be taken into account.

\section{Materials and Methods}

The experiments and climatic conditions have already been described in a previous paper (Lemaire and. Culleton, 1989). Nitrogen yield in the sward during spring growth was determined by analysis of nitrogen content of the biomass harvested by a reciprocating mower, as already described in the previous paper. Treatments (nitrogen application and date of last cut in autumn) were laid out in a randomised block design. The main plots were divided into subplots of $3 \mathrm{~m}^{2}$. At each date one subplot was cut in order to obtain the nitrogen yield course during spring.

During winter at 3 -week intervals following the autumn cut, the quantities of nitrogen in the aerial biomass were determined from measurements of dry matter biomass and nitrogen content of 8 turves (Lemaire and Culleton, 1989). Separation of the aerial biomass into green lamina, green sheath and dead material allowed us to determine the quantity of nitrogen present in these fractions.

During the same period, as described in Lemaire and Culleton (1989), leaf elongation (L) and leaf senescence (S) were determined on each of 20 labelled tillers in each treatment.

\section{Model for the estimation of nitrogen fluxes}

Fluxes of nitrogen between the soil and sward and between the sward components has been studied according to the scheme presented in Figure 1.

The uptake of nitrogen in the period between the autumn harvest and a subsequent time $t(\mathrm{Tt})$ may be calculated as the total nitrogen content $\mathrm{Nt}$ of the live biomass in the period to time $\mathrm{t}$ less the nitrogen content No of the live biomass remaining after the autumn cut. Nevertheless, it is necessary to take into account the quantity of nitrogen returning to the litter throuth senescence of leaves Lt. So nitrogen uptake Ut may be calculated as follows:

$$
\mathrm{Ut}=\mathrm{Nt}-\mathrm{No}+\mathrm{Lt}
$$

The total nitrogen at time $t(\mathrm{Nt})$ is the sum of the nitrogen content of the tiller population which was present at the autumn harvest $(\mathrm{Ft})$ and of the nitrogen content of the population of new tillers emerged in the period after the harvest $(\mathrm{St})$ :

$$
\mathrm{Nt}=\mathrm{Ft}+\mathrm{St}
$$

The nitrogen content in old tillers which were present at the autumn cut $(\mathrm{Ft})$ can be calculated by the following equation:

$$
\mathrm{Ft}=((1+\alpha)(\mathrm{E}-\mathrm{S}) \cdot \mathrm{g} \cdot \mathrm{Ng} \cdot \mathrm{To})+\mathrm{No}
$$

where $E$ and $S$ are respectively accumulated elongation and accumulated senescence of lamina measured on tillers labelled just after the autumn cut and expressed in $\mathrm{cm}$ per tiller, $\mathrm{g}$ is the weight per unit length of green lamina, $\mathrm{Ng}$ is \% nitrogen of green lamina and To is the number of tillers after the autumn cut. The coefficient $\alpha$ is introduced to take into account the nitrogen content of the sheath. In the absence of direct measurements of sheath senescence we assume that dry matter and therefore sheath nitrogen is returned to the litter in the same proportion as is lamina nitrogen. If this hypothesis is accepted, the coefficient $\alpha$ is the ratio between the quantities of nitrogen of sheath biomass and of lamina biomass. 


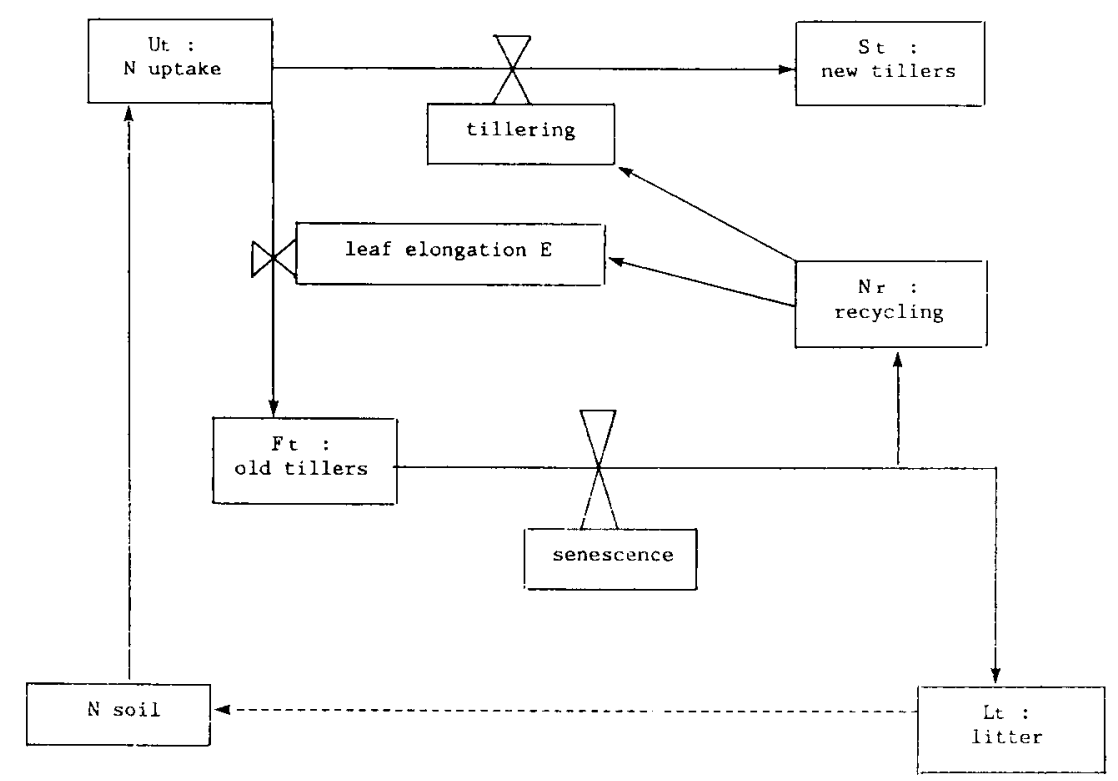

Fig. 1. Scheme of nitrogen fluxes in sward. Ut: Nitrogen uptake by aerial parts; Ft: Nitrogen used for leaf growth on tillers developed before autumn cut; St: Nitrogen used for growth of tillers that appeared after autumn cut; Lt: Nitrogen lost by decay of dead material; Nr: Nitrogen recycling during leaf senescence.

The quantity of nitrogen transferred to the litter (Lt) can be estimated by the following equation:

$$
\mathrm{Lt}=(1+\alpha) \cdot \mathrm{S} \cdot \mathrm{S} \cdot \mathrm{Ns} \cdot \mathrm{To}
$$

where $S$ is the cumulated senescence of lamina expressed in $\mathrm{cm}^{-}$tiller-1, $^{-1} \mathrm{~s}$ is the weight per unit length of the yellowing part of senescing lamina, Ns is the \% of nitrogen of the yellowing part of senescing lamina and To is the initial number of tillers (at the autumn harvest). As for equation (3), the coefficient $\alpha$ is introduced to take into account the nitrogen of the sheath.

The total nitrogen of the live biomass Nt may be determined directly by analysis of field samples, and the nitrogen content of the population of new tillers emerged after the autumn cut (St) may be calculated using equation (3). For these new tillers, senescence was delayed for 2 leaf appearance intervals (Lemaire, 1985), and as this period was not exceeded, senescence was considered to be negligible.

So the quantity of nitrogen recycled from senescing leaves to new leaves $(\mathrm{Nr})$ may be calculated by the following equation:

$$
\mathrm{Nr}=(1+\alpha) \cdot \mathrm{S} \cdot(\mathrm{g} \cdot \mathrm{Ng}-\mathrm{s} \cdot \mathrm{Ns}) \cdot \mathrm{To}
$$

The determination of $g$ (weight per unit length of green lamina) and $s$ (weight per unit length of dead lamina) were carried out only during the winter of 1982-1983. In that year, 40 tillers were taken randomly and the length and the weight of the total green lamina part and the length and weight of the dead lamina part were measured separately. $\mathrm{Ng}$ and $\mathrm{Ns}$ were measured on the 2 samples by analysis of Kjeldhal after drying.

\section{Results}

\section{Nitrogen yield during spring regrowth}

Table I gives the quantity of nitrogen harvested during spring for the 3 years' duration of experiment 1 . The quantity harvested varied between years, depending on the dry matter accumulation. The apparent recovery of the $60 \mathrm{~kg} \mathrm{~N}$ applied in autumn was $\approx 20 \mathrm{~kg} \mathrm{~N}$ in 1979-1980, $50 \mathrm{~kg}$ in 1980-1981 and $40 \mathrm{~kg}$ in 1981-1982. The apparent recovery coefficients were 30,83 and $67 \%$, respectively. The maximum recovery rates were, in general, obtained at the earlier harvest dates. There was no effect of autumn nitrogen application on percentage nitrogen of the grass in spring, indicating no residual $\mathrm{N}$ effect.

Figure 2 summarises the nitrogen accumulation in harvestable biomass for 1982-1983 (experiment 2) and 1984-1985 (experiment 3) for the 2 differing dates of cut in autumn. After an earlier cut in autumn the recovery of nitrogen was $35 \mathrm{~kg} \mathrm{~N}$ in 1982-1983 and $30 \mathrm{~kg} \mathrm{~N}$ in 1984-1985. After the late cut in autumn 19821983 the recovery was only $20 \mathrm{~kg} \mathrm{~N}$. However, the apparent recovery of nitrogen was not affected by the delayed cut in 1984-1985 despite the very cold weather. These results are in agreement with the dry matter accumulation shown in the previous paper (Lemaire and Culleton, 1989).

\section{Nitrogen accumulation by the sward during win-} ter

The results so far presented show that nitrogen applied in the autumn was accumulated by the 
Table l. Experiment 1: dry matter yield, nitrogen yield and nitrogen content of tall fescue in spring that had received 60 $\mathrm{kg}$ or $0 \mathrm{~kg} \mathrm{~N}$ during the previous autumn.

\begin{tabular}{|c|c|c|c|c|c|c|}
\hline \multirow[t]{2}{*}{ 1979-1980: } & \multicolumn{2}{|c|}{03 April } & \multicolumn{2}{|c|}{16 April } & \multicolumn{2}{|c|}{29 April } \\
\hline & $O N$ & $60 N$ & $O N$ & $60 N$ & $O N$ & $60 N$ \\
\hline DM $t \cdot h a^{-1}$ & 1.17 & 1.53 & 2.71 & 3.08 & 4.70 & 5.40 \\
\hline$N \%$ & 3.89 & 4.25 & 3.03 & 3.21 & 2.31 & 2.31 \\
\hline N kg ha-1 & 45 & 65 & 82 & 99 & 109 & 125 \\
\hline $\operatorname{LSD}(0.05)$ & & & & & & \\
\hline \multirow[t]{2}{*}{ 1980-1981: } & \multicolumn{2}{|c|}{08 April } & \multicolumn{2}{|c|}{15 April } & \multicolumn{2}{|c|}{28 April } \\
\hline & $O N$ & $60 N$ & $O N$ & $60 N$ & $O N$ & $60 N$ \\
\hline DM $t \cdot h a^{-1}$ & 2.32 & 4.07 & 3.62 & 5.01 & 5.37 & 7.22 \\
\hline $\mathrm{N} \%$ & 2.97 & 2.87 & 2.66 & 2.80 & 2.72 & 2.74 \\
\hline N kg ha-1 & 69 & 117 & 96 & 140 & 146 & 198 \\
\hline $\operatorname{LSD}(0.05)$ & & & & & & \\
\hline \multirow[t]{2}{*}{ 1981-1982: } & \multicolumn{2}{|c|}{02 April } & \multicolumn{2}{|c|}{16 April } & \multicolumn{2}{|c|}{28 April } \\
\hline & $O N$ & $60 N$ & $O N$ & $60 N$ & $O N$ & $60 N$ \\
\hline DM $t \cdot h a^{-1}$ & 1.11 & 2.64 & 2.46 & 4.00 & 3.83 & 5.62 \\
\hline $\mathrm{N} \%$ & 2.99 & 2.89 & 2.71 & 2.67 & 1.99 & 2.01 \\
\hline N kg ha-1 & 33 & 76 & 67 & 107 & 76 & 113 \\
\hline $\operatorname{LSD}(0.05)$ & \multicolumn{2}{|c|}{8} & \multicolumn{2}{|c|}{11} & \multicolumn{2}{|c|}{10} \\
\hline
\end{tabular}

( $L S D$ is calculated for $\mathrm{N} \mathrm{kg} \cdot \mathrm{ha}^{-1}$ ).
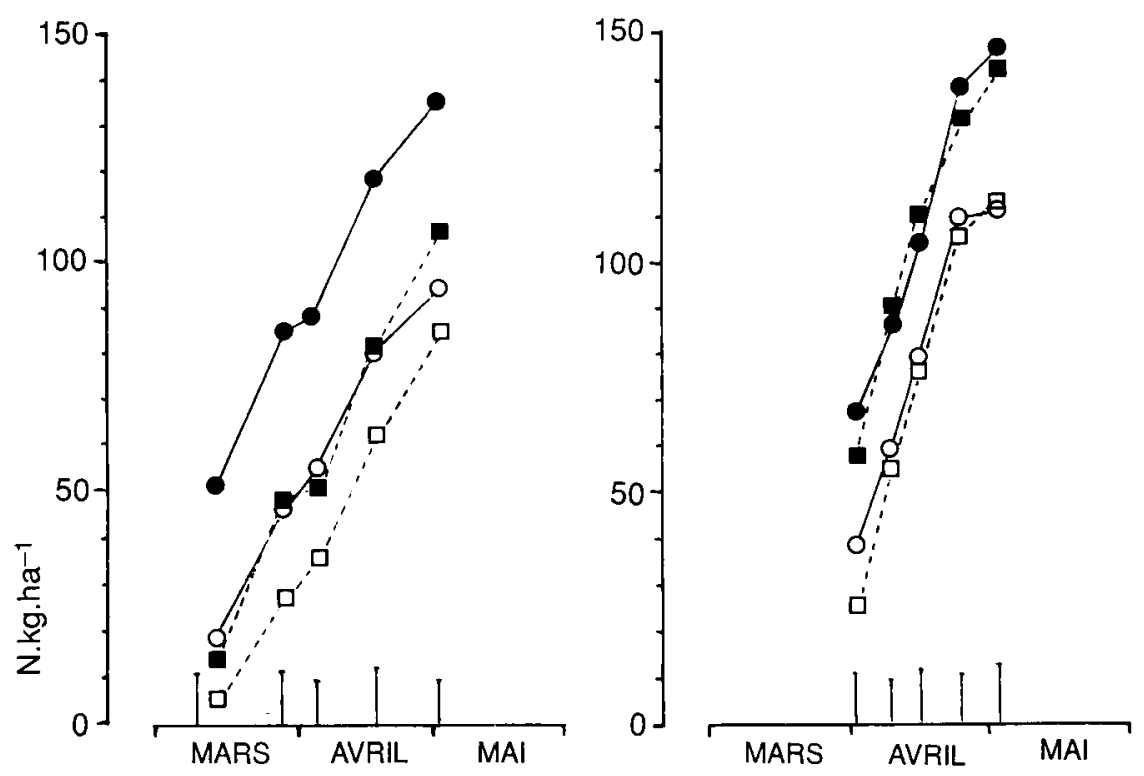

Fig. 2. Accumulated nitrogen yield in spring for experiment 2, 1982-1983 and experiment 3, 1984-1985. Early cut (D1) $0 \mathrm{~kg} \mathrm{~N} \cdot \mathrm{ha}^{-1}, 0 ; 60 \mathrm{~kg} \mathrm{~N} \cdot \mathrm{ha}^{-1}, \bullet$. Late cut (D2) $0 \mathrm{~kg} \mathrm{~N} \cdot \mathrm{ha}^{-1}, 0 ; 60 \mathrm{~kg} \mathrm{~N} \cdot \mathrm{ha}^{-1}, \mathbf{0}$. Vertical bars represent $\operatorname{LSD}(0.05)$. 
sward during winter and that no residual nitrogen was carried into the spring,

Figure 3 shows the quantities of nitrogen accumulated in the living aerial biomass during the winter for experiment 1 . It shows that after the end of November no more nitrogen was recovered. Figure 4 shows the same data for experiments 2 and 3 . The results from the early autumn cut were similar to those obtained in the previous experiment. The maximum recovery of nitrogen was reached by mid-December. After this point, the quantity of nitrogen in the aerial parts remained constant during the winter of 1982-1983 (experiment 2), but decreased from $65 \mathrm{~kg}$ to $45 \mathrm{~kg}$ in 1984-1985 (experiment 3) during the cold frosty period. After the late cut in autumn 1982-1983, the recovery of nitrogen was much slower and less marked: only $15 \mathrm{~kg} \mathrm{~N}$ by 10 March as against $39 \mathrm{~kg}$ for the earlier cut. However, in 1984-1985 nitrogen recovery was similar for both cutting dates, $25 \mathrm{~kg} \mathrm{~N}$ for the late cut and $30 \mathrm{~kg} \mathrm{~N}$ for the earlier cut.

The quantities of nitrogen contained in the dead biomass were similar from year to year and were constant during the winther, the values all lying between $15-20 \mathrm{~kg}$. The differences between 0 and $60 \mathrm{~kg} \mathrm{~N}$ plots were very low or were not significantly different. These data do not correspond to a measurement of nitrogen flux from plant to soil by senescence and litter decomposition. The constant quantity of nitrogen found in the dead biomass suggests therefore that the input of nitrogen into the dead biomass by senescence is approximately equal to the output by litter decay.

Estimation of nitrogen fluxes between the soil and aerial plant parts during winter

Figure 5 gives the cumulated elongation $(E)$ and cumulated senescence (S) of lamina during winter 1982-1983 (experiment 2) on tillers that were labelled in autumn.

Table II summarises the data on $\mathrm{g}$ (weight per unit of length of green lamina) and $s$ (weight per unit of lenght of dead lamina) during winter 1982-1983 (experiment 2). There were no important differences between treatments and both remained relatively constant during winter; $g$ averaged $2.0 \mathrm{mg} \cdot \mathrm{cm}^{-1}$ and $\mathrm{s}$ averaged $1.3 \mathrm{mg}$ $\mathrm{cm}^{-1}$.

Table III summarises the nitrogen content of green lamina $(\mathrm{Ng})$, of dead lamina (Ns), and of sheath during the winter of 1982-1983. Nitrogen applied in autumn had an important effect on nitrogen content of green lamina and sheath, but only had a small though significant effect on nitrogen content of dead lamina. The values for green tissue decreased slowly during the winter, while

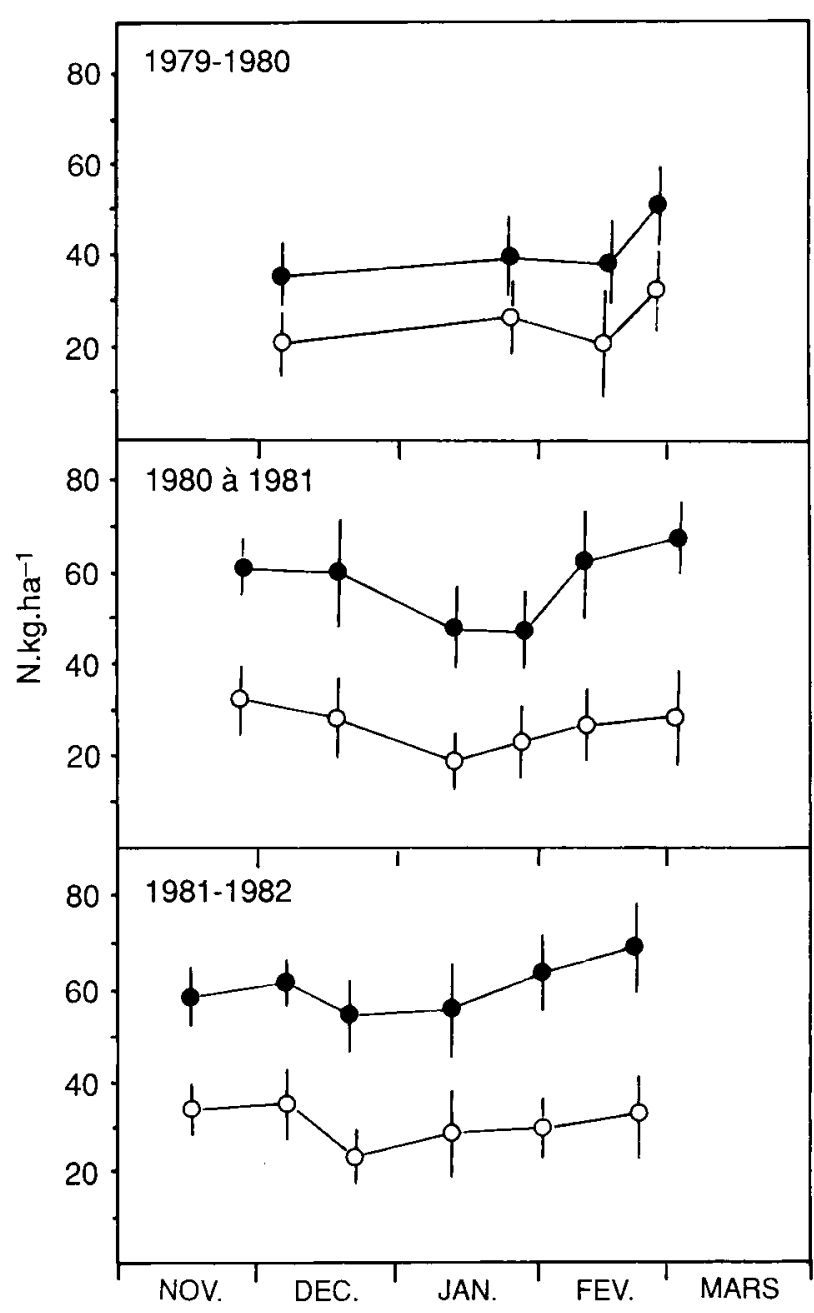

Fig. 3. Pattern of nitrogen accumulation in the aerial biomass (Nt) during the winters 1979-1980, 1980-1981, 1981-1982, in experiment $1.0,0 \mathrm{~kg} \mathrm{~N} \cdot \mathrm{ha}^{-1} ; 00 \mathrm{~kg} \mathrm{~N} \cdot \mathrm{ha}^{-1}$. Vertical bars represent confidence intervals $(P=0.05)$.

they remained more constant for the dead lamina.

The number of tillers, $T$, in spring 1983 in experiment 2 , was estimated to be approximately equal to 3,000 tillers $\mathrm{m}^{-2}$ (Lemaire and Culleton, 1989). S (cumulated senescence) reached a value of $33 \mathrm{~cm}$ for $60 \mathrm{~kg} \mathrm{~N}$ and $25 \mathrm{~cm}$ for $0 \mathrm{~kg} \mathrm{~N}$ after the early cut in autumn (D1) and 13 and $11 \mathrm{~cm}$ for $60 \mathrm{~kg}$ and $0 \mathrm{~kg} \mathrm{~N}$ respectively after the late cut in autumn (D2) (Fig. 5).

The ratio between quantities of nitrogen in laminae and sheaths $(\alpha)$ appeared relatively constant during winter and was equal to 0.37. By using these values and the mean values for $s$ and Ns from Tables II and III, estimations have been made of the quantities of nitrogen which were returned to litter by senescence of the sward for the different treatments during the winter of 1982-1983, and these values are given in Table IV.

Nitrogen uptake Ut by the sward during winter can be derived by using equation (3). These 
Table II. Changes in weight per unit length of green lamina (g) and dead lamina (s) $\left(\mathrm{mg} \cdot \mathrm{cm}^{-1}\right)$ during winter.

\begin{tabular}{|c|c|c|c|c|c|}
\hline & \multicolumn{2}{|c|}{$\begin{array}{l}\text { D1 } \\
\text { (Early cut in autumn) }\end{array}$} & \multicolumn{2}{|c|}{$\begin{array}{l}\text { D2 } \\
\text { (Late cut in autumn) }\end{array}$} & \multirow[t]{2}{*}{ Mean } \\
\hline & $O N$ & $60 N$ & $O N$ & $60 N$ & \\
\hline \multicolumn{6}{|l|}{13 January } \\
\hline \multirow{2}{*}{$\begin{array}{l}\text { Green Lamina }(\mathrm{g}) \\
\text { Dead Lamina }(\mathrm{s})\end{array}$} & 2.16 & 1.90 & 2.00 & 1.92 & 2.00 \\
\hline & \multicolumn{5}{|c|}{ Not measured } \\
\hline \multicolumn{6}{|l|}{19 February } \\
\hline Green Lamina & 1.93 & 1.85 & 1.79 & 1.87 & 1.86 \\
\hline Dead Lamina & 1.28 & 1.46 & 1.49 & 1.44 & 1.42 \\
\hline \multicolumn{6}{|l|}{11 March } \\
\hline Green Lamina & 2.24 & 1.98 & 2.12 & 1.97 & 2.08 \\
\hline Dead Lamina & 1.22 & 1.16 & 1.16 & 1.30 & 1.21 \\
\hline \multicolumn{6}{|l|}{ Mean Values } \\
\hline Green Lamina & 2.11 & 1.91 & 1.97 & 1.92 & 1.98 \\
\hline Dead Lamina & 1.25 & 1.21 & 1.33 & 1.37 & 1.32 \\
\hline
\end{tabular}

Table III. Changes in nitrogen content of green lamina ( $\mathrm{Ng}$ ), sheath and dead lamina (Ns) during winter 1982-1983.

\begin{tabular}{|c|c|c|c|c|c|}
\hline & \multicolumn{2}{|c|}{ Early cut } & \multicolumn{2}{|c|}{ Late cut } & \multirow{2}{*}{$\begin{array}{l}\angle S D \\
(0.05)\end{array}$} \\
\hline & $O N$ & $60 N$ & $O N$ & $60 N$ & \\
\hline \multicolumn{6}{|l|}{23 November } \\
\hline Green lamina $(\mathrm{Ng})$ & 4.03 & 4.47 & \multicolumn{2}{|c|}{ Not measured } & 0.31 \\
\hline Sheath & 2.28 & 3.01 & \multicolumn{2}{|c|}{ Not measured } & 0.25 \\
\hline Dead lamina (Ns) & 0.79 & 0.94 & \multicolumn{2}{|c|}{ Not measured } & 0.11 \\
\hline \multicolumn{6}{|l|}{14 December } \\
\hline Green lamina & 3.65 & 4.58 & 3.98 & 3.80 & 0.27 \\
\hline Sheath & 2.28 & 3.40 & 2.31 & 2.74 & 0.21 \\
\hline Dead lamina & 0.85 & 1.01 & 0.88 & 0.86 & 0.12 \\
\hline \multicolumn{6}{|l|}{11 January } \\
\hline Green lamina & 2.89 & 3.79 & 3.51 & 4.09 & 0.26 \\
\hline Sheath & 2.48 & 3.30 & 2.50 & 3.11 & 0.22 \\
\hline Dead lamina & 0.83 & 0.92 & 0.74 & 0.78 & 0.10 \\
\hline \multicolumn{6}{|l|}{09 February } \\
\hline Green lamina & 3.07 & 3.52 & 3.54 & 3.80 & 0.32 \\
\hline Sheath & 2.00 & 2.76 & 2.36 & 2.88 & 0.17 \\
\hline Dead lamina & 1.01 & 1.26 & 0.83 & 0.92 & 0.12 \\
\hline \multicolumn{6}{|l|}{08 March } \\
\hline Green lamina & 2.75 & 3.23 & 2.99 & 3.32 & 0.21 \\
\hline Sheath & 1.73 & 2.09 & 1.95 & 2.17 & 0.19 \\
\hline Dead lamina & 0.97 & 1.37 & 0.99 & 1.14 & 0.13 \\
\hline \multicolumn{6}{|l|}{ Mean values } \\
\hline Green lamina & 3.28 & 3.92 & 3.51 & 3.75 & \\
\hline Sheath & 2.13 & 2.91 & 2.28 & 2.73 & \\
\hline Dead lamina & 0.89 & 1.11 & 0.86 & 0.93 & \\
\hline
\end{tabular}




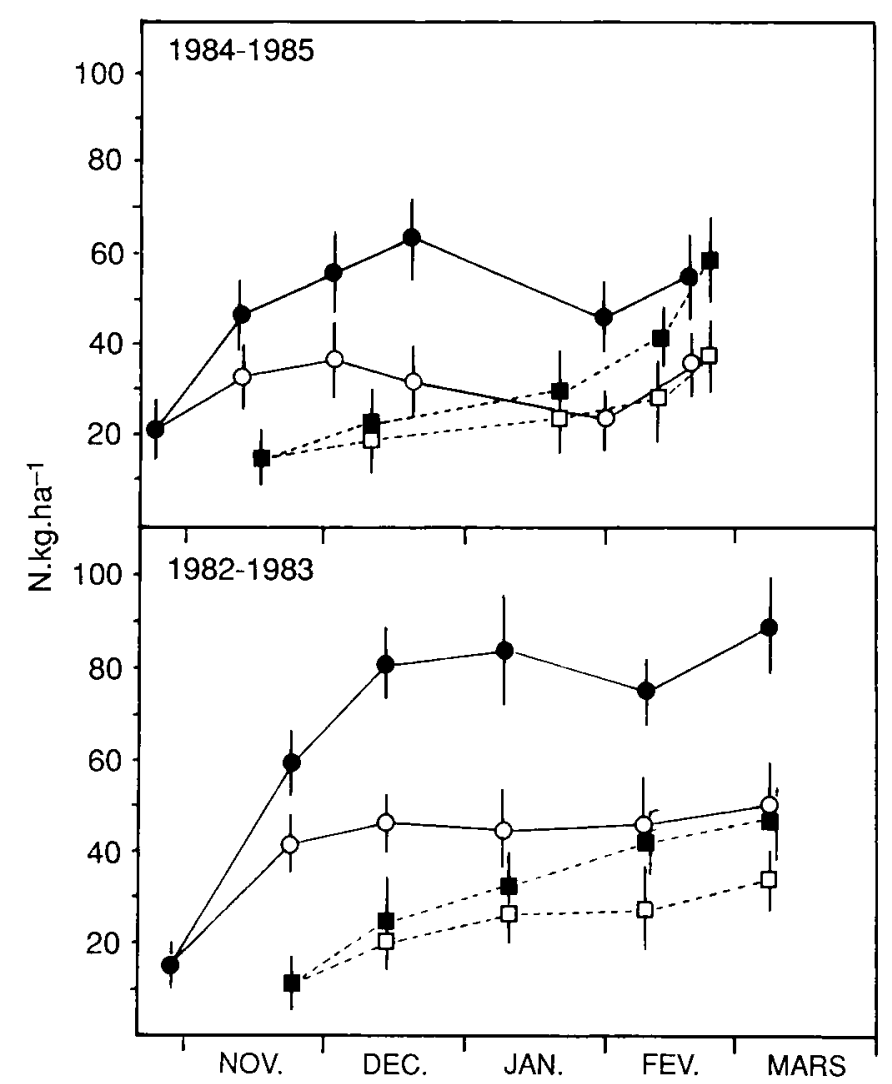

Fig. 4. Pattern of nitrogen accumulation in the aerial biomass (Nt) during the winters of 1982-1983 (experiment 2) and 1984-1985 (experiment 3). Early cut (D1) $0 \mathrm{~kg} \mathrm{~N}$. ha-1, O; $60 \mathrm{~kg} \mathrm{~N} \cdot \mathrm{ha}^{-1}, \bullet$. Late cut (D2) $0 \mathrm{~kg} \mathrm{~N} \cdot \mathrm{ha}^{-1}, \square ; 60 \mathrm{~kg}$ $\mathrm{N}$. ha ${ }^{-1}, \mathbf{n}$. Vertical bars represent confidence intervals $(P=$ 0.05).

values are given in Table IV. Nitrogen application after the early cut in autumn (D1) allowed extra uptake of nitrogen to the level of $45 \mathrm{~kg}$ (this corresponds to an apparent recovery coefficient of $75 \%$ ). However, after the late cut in autumn the apparent recovery rate was only $17 \mathrm{~kg}(28 \%)$.

The turnorer of nitrogen is expressed by the ratio $\mathrm{Nr} / \mathrm{Nt}$. This ratio was, as expected, higher after an early cut in autumn than after a late cut. These results show that nitrogen is more efficiently recycled when nitrogen nutrition is deficient, as had been previously demonstrated by Gastal (1984) in controlled conditions.

Similar estimations for the winter of 1984-1985 have been made using the average values for $\mathrm{g}$ and $\mathrm{s}$ that were calculated for 1982-1983. Table IV shows that values for Lt were similar to that in 1982-1983. The nitrogen recycled $(\mathrm{Nr})$ seemed to be more restricted than in $1982-1983$. The ratio $\mathrm{Nr} /(\mathrm{Nr}+\mathrm{Lt})$ represents the percentage of nitrogen recycling during leaf senescence. This value was $\approx 0.83$ in 1982-1983 and seemed independent of treatments. However, this ratio was lower in 1984-1985 (0.75) and particularly low for treatment D1. N 60.

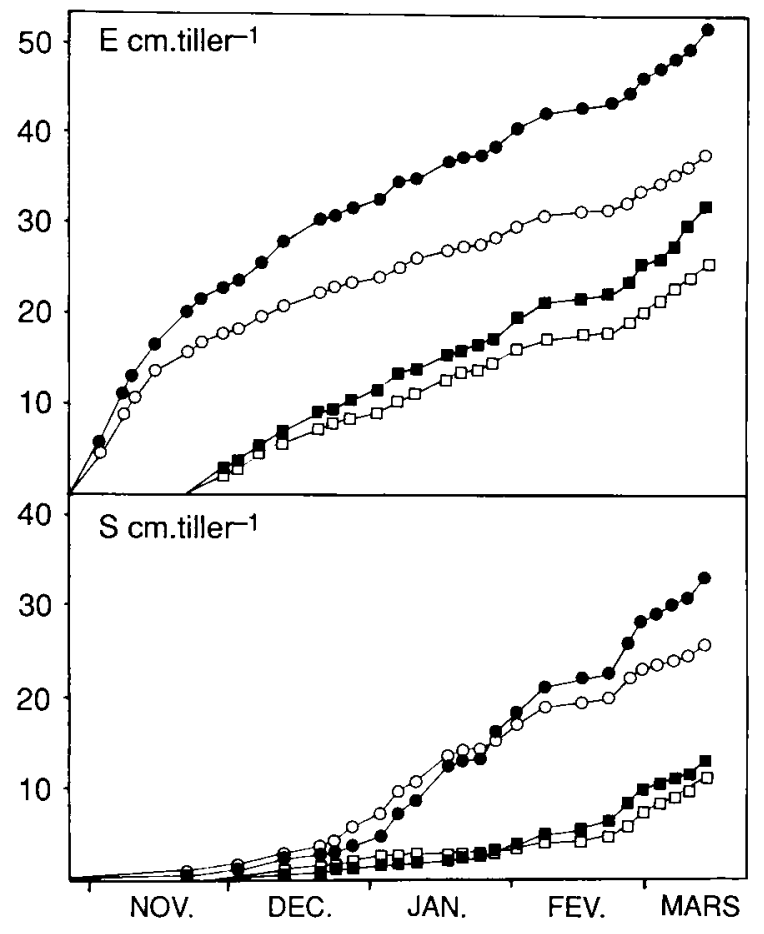

Fig. 5. Accumulated elongation $(E)$ and accumulated senescence $(S)$ on tillers labelled in autumn. The data are from experiment 2, 1982-1983. Early cut (D1) $0 \mathrm{~kg} \mathrm{~N} \cdot \mathrm{ha}^{-1}, \mathrm{O}$; $60 \mathrm{~kg} \mathrm{~N} \cdot \mathrm{ha}^{-1}, \bullet$. Late cut (D2) $0 \mathrm{~kg} \mathrm{~N} \cdot \mathrm{ha}^{-1}, \square ; 60 \mathrm{~kg} \mathrm{~N}$. $\mathrm{ha}^{-1}, \mathbf{\square}$.

Nitrogen used for tillering during the winter (St) was calculated indirectly using equations (2) and (3). The parameters in equation (3) were estimated on tillers that were labelled at the date of autumn cut, while $\mathrm{Nt}$ in equation (2) was estimated from the total population. This anomaly leads to an over estimation of nitrogen in the old tiller population, because tillers labelled in autumn tended to be bigger than the average of the population of tillers at this date. This is due to the fact that bigger tillers tended to be selected for labelling in the field. This over estimation has been quantified by the comparison of the value of $\mathrm{Nt}$ and $\mathrm{Ft}$ (old tillers) on 23 November 1982. At this date it can be assumed that the weight of the new tillers that appeared since the autumn cut was negligible and consequently $\mathrm{Ft}$ (old tillers) should be close to $\mathrm{Nt}$ if no sampling errors existed. In fact, the Ft/Nt ratio is $\approx 1.2$ on that date. It has been assumed that this over estimation of $\mathrm{Ft}$ (old tillers) of $20 \%$ was similar during the entire winter because the measurements made on $\mathrm{E}$ and $S$ were made on the same population of labelled tillers throughout the winter. The value for $\mathrm{Ft}$ calculated by equation (3) has been corrected to take this over estimation into account.

\section{Discussion}

Figure 6 summarises the results obtained from 
Table IV. Estimation of the importance of nitrogen fluxes between soil and sward and within the sward during winter according to the model presented in Fig 1.

\begin{tabular}{|c|c|c|c|c|c|}
\hline \multirow[t]{2}{*}{ 1982-1983: } & \multicolumn{2}{|l|}{$D 1$} & \multicolumn{2}{|l|}{$D 2$} & \\
\hline & $O N$ & $60 \mathrm{~N}$ & $O N$ & $60 N$ & \\
\hline $\begin{array}{l}\text { Nt Nitrogen contained } \\
\text { in aerial biomass }\end{array}$ & 50 & 89 & 33 & 48 & \\
\hline $\begin{array}{l}\text { Ut Nitrogen uptake by } \\
\text { sward }\end{array}$ & 62 & 107 & 38 & 55 & \\
\hline $\begin{array}{l}\text { Lt Return of nitrogen to } \\
\text { soil by litter decay }\end{array}$ & 12 & 18 & 5 & 7 & \\
\hline $\begin{array}{c}\mathrm{Nr} \quad \begin{array}{c}\text { Nitrogen recycling } \\
\text { inside the sward }\end{array}\end{array}$ & 56 & 86 & 27 & 33 & \\
\hline Turnover Nr/Nt & 1.12 & 0.97 & 0.82 & 0.69 & \\
\hline $\mathrm{Nr} /(\mathrm{Nr}+\mathrm{Lt})$ & 0.82 & 0.83 & 0.84 & 0.83 & $(0.83)$ \\
\hline \multirow[t]{2}{*}{ 1984-1985: } & \multicolumn{2}{|l|}{ D1 } & \multicolumn{2}{|l|}{$D 2$} & \\
\hline & $O N$ & $60 N$ & $O N$ & $60 N$ & \\
\hline $\begin{array}{l}\mathrm{Nr} \text { Nitrogen contained } \\
\text { in aerial biomass }\end{array}$ & 36 & 55 & 33 & 52 & \\
\hline $\begin{array}{l}\text { Ut Nitrogen uptake by } \\
\text { sward }\end{array}$ & 48 & 75 & 38 & 60 & \\
\hline $\begin{array}{l}\text { Lt Return of nitrogen to } \\
\text { soil by litter decay }\end{array}$ & 12 & 20 & 5 & 8 & \\
\hline $\begin{array}{l}\mathrm{Nr} \text { Nitrogen recycling } \\
\text { inside the sward }\end{array}$ & 42 & 47 & 16 & 24 & \\
\hline Turnover $\mathrm{Nr} / \mathrm{Nt}$ & 1.17 & 0.85 & 0.48 & 0.46 & \\
\hline $\mathrm{Nr} /(\mathrm{Nr}+\mathrm{Lt})$ & 0.78 & 0.70 & 0.76 & 0.75 & $(0.75)$ \\
\hline
\end{tabular}

Calculations are made for the period from date of autumn cut to March 10 .

1982-1983. By the end of winter between $40-50 \%$ of the nitrogen in the total aerial biomass was present in the new tillers which appeared during the winter. $\mathrm{N}$ nitrogen taken up by the old tillers had ceased by 15 December. It can be assumed therefore that the nitrogen used for tillering during winter was for the most part recycled nitrogen from old tillers, present at the firial autumn cut.

The final size of a leaf is affected by the ternperature during its growth (Robson, 1973; Lemaire, 1985). In January and February the leaves that were senescing were those that appeared in November and these were large $(19 \mathrm{~cm})$ because they grew in relatively high temperatures. The leaves being formed in January and February were smaller $(11 \mathrm{~cm})$ because they grew at lower temperatures. The substitution of large leaves by small ones releases a surplus of nitrogen which becomes available for development of tiller buds during a period when nitrogen uptake from the soil is low.
The results presented here from different experiments are in good agreement between themselves. Nevertheless, the simulation of nitrogen fluxes between the sward and the soil and between plant parts can be discussed. For this purpose we have considered that any leaching of nitrogen during leaf senescence was negligible. Wether this is so is not very clear from the literature. Hunt (1983) found a recycling of $N$ from senescing leaves between $30-50 \%$, but he worked with very high levels of nitrogen applications, and said that recycling was enhanced with lower levels of nitrogen nutrition. Clark (1977) considered leaching from senescent leaves to be negligible, but Long et al. (1956) have estimated up to $10 \%$ of $\mathrm{N}$ can be leached during leaf senescence. On the other hand, Thomas and Stoddart (1980) have demonstrated clearly the role of senescent leaves as a direct source of nutrients by recycling,

Nitrogen application in the autumn after the last cut appears to be a good way for improving 


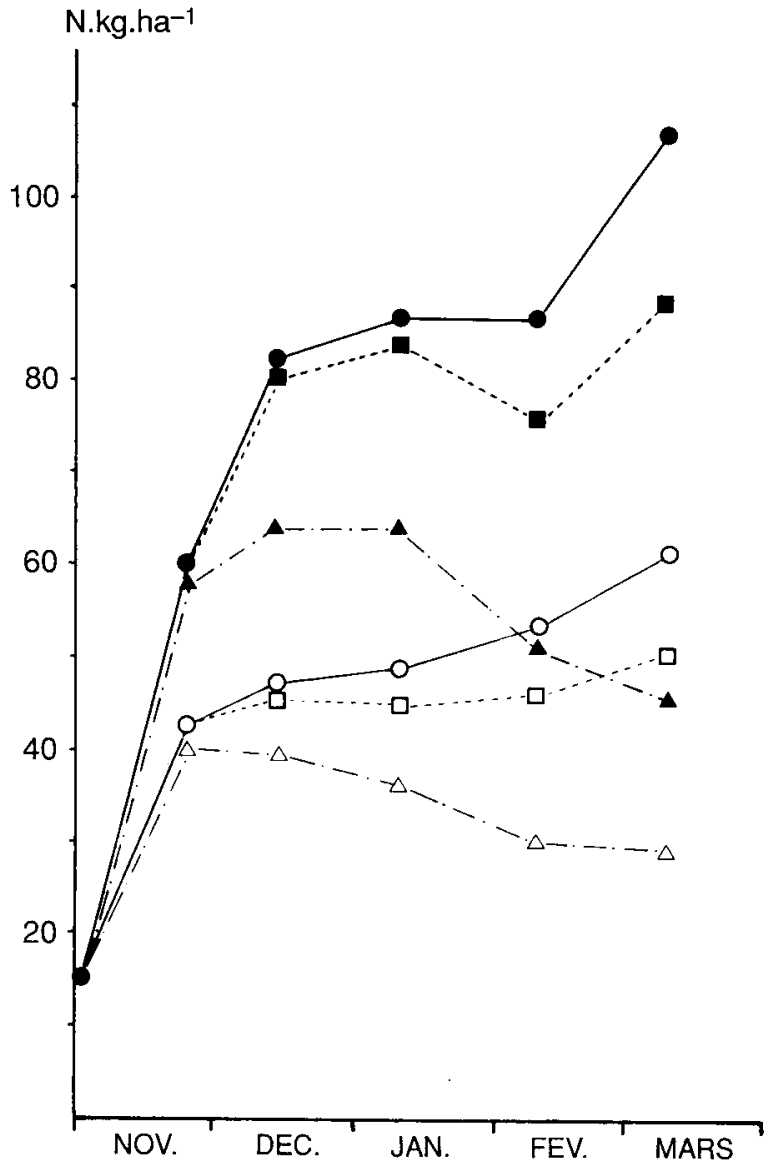

Fig. 6. Experiment 2: Nitrogen uptake Ut $(\bullet, O)$; nitrogen accumulation in live aerial biomass $\mathrm{Nt}(\boldsymbol{\square}, 0)$; and nitrogen accumulation in old tillers $\mathrm{Ft}(\boldsymbol{\Lambda}, \Delta)$ during winter 1982-1983 after an early cut in autumn and according to no nitrogen application (white symbols) or $60 \mathrm{~kg} \mathrm{~N}$ (dark symbols). The difference between $\mathrm{Ut}$ and $\mathrm{Nt}$ indicate the quantities of nitrogen returning to the soil by litter: Lt. The difference between $\mathrm{Nt}$ and $\mathrm{Ft}$ indicate the quantity of nitrogen accumulated in new tillers: St.

earliness of grass growth in spring. This effect is mainly due to the enhancement of tillering rates. The risk of leaching of nitrate during winter appears relatively low if we consider the rapidity of nitrogen recovery in the aerial biomass. However, nitrogen should not be applied too late in autumn. The risk of frost damage to tall fescue being increased by nitrogen application does not seem to be too important if we consider the results obtained during the very cold winter of 1984-1985. Nevertheless, it would be dangerous to extrapolate these results to more continental climatic conditions.

The simulation of nitrogen fluxes indicates that nitrogen uptake is very low between mid-December to mid-February when the soil temperature is low. More precise information is needed about the effect of root temperature on nitrogen absorption for grasses. The low quantities of nitrogen returning to the soil via the litter suggests that the recycling of protein $\mathrm{N}$ from senescent leaves to young leaves is of major importance.

The increase in number of tillers during winter appears to be the main factor explaining the earliness of growth in spring (Lemaire and Culleton, 1989). Nitrogen nutrition in autumn improves tillering, and a large proportion of nitrogen uptake before winter is recycled from old tillers to new ones. This effect of nitrogen requires in depth study with attention paid to the interaction of autumn management strategies of the sward for optimising tillering during winter.

\section{Acknowledgments}

The authors thank A.J. Brereton and S.A. Grant for their criticisms, and suggestions for clarifying the manuscript.

\section{References}

Clark F.E. (1977) Internal cycling of 15-nitrogen in short grass prairie. Ecology 58, 1322-1333

Corall A.J. \& Clement C.R. (1965) Úptake of nitrate in winter by two ecotypes of Festuca arundinacea Schreb. Nature 206, 4979-109

Gastal F. (1984) Echanges de $\mathrm{CO}_{2}$ et croissance de la fétuque élevée en interaction avec la fumure azotée. Thèse de $3^{e}$ cycle, Université de Paris-Sud, Orsay Hunt W.F. (1983) Nitrogen cycling through senescent leaves and litter in swards of Ruanui and Nui ryegrass with high and low nitrogen inputs. N. Z. J. Agric. Res. 26, $461-471$

Jones M.B., Delwiche C.C. \& Williams W.A. (1977) Uptake and losses of $15 \mathrm{~N}$ applied to annual grass and clover in lysimeters. Agron. J. 69, 6, 1019-1023

Lemaire G. (1985) Cinétique de croissance d'un peuplement de fétuque élevée (Festuca arundinacea Schreb.) pendant l'hiver et le printemps. Effets des facteurs climatiques. Thèse de Doctorat d'Etat, Université de Caen

Lemaire G. \& Culleton N. (1989) Effects of nitrogen applied after the last cut in autumn on a tall fescue sward. I. Analysis of morphogenesis during winter and subsequent growth in spring. Agronomie 9, 2

Long W.G., Sweet D.V. \& Tuckey M.B. (1956) Leaching of organic compounds from leaves. Science 123 , 1039-1040

Robson M.J. (1973) The effect of temperature on the growth of S170 tall fescue (Festuca arundinacea Schreb.). II. Independant variation of day and night temperature. J. Appl. Ecol. 10, 1, 93-105

Savage G. (1978) Growing extra winter feed with nitrogen. J. Agric. Victoria 76, 5, 190-194

Thomas H. \& Stoddart J.L. (1980) Leaf senescence. Annu. Rev. Plant Physiol. 31, 83-111

Tomka O. \& Lihan E. (1976) Effect of autumn and spring dates of application of nitrogen fertilizer on the herbage yield and crude protein content in dry matter. Proceedings 13th Int. Grassl. Congress, Sect. 7, Leipzing, pp. 935-939 